\title{
PHYSICAL AND CHEMICAL PROPERTIES OF SURFACE WATERS IN THE RÓŻANY STRUMIEŃ CATCHMENT IN THE YEARS 1988-2012
}

\author{
Monika OKońsKa, Katarzyna Pietrewicz \\ Institute of Physical Geography and Environmental Planning, Adam Mickiewicz University in Poznań, Poland
}

Manuscript received: December 6, 2016

Revised version: January 20, 2016

\begin{abstract}
OKоŃSKa M., Pietrewicz K., 2017. Physical and chemical properties of surface waters in the Różany Strumień catchment in the years 1988-2012. Quaestiones Geographicae 36(1), Bogucki Wydawnictwo Naukowe, Poznań, pp. 33-49, 13 figs, 4 tables.

ABSTRACT: The Różany Strumien catchment located in the north of Poznań is an example of a small anthropogenically-induced catchment. The main aim of this study is to analyse the variability of selected physical and chemical properties of surface waters in the catchment area in the years 1988-2012. It was found that surface waters in the catchment can be classified as hard and very hard, with slightly basic $\mathrm{pH}$. The deterioration of Różany Strumień water quality concerns chemical oxygen demand, conductivity, chlorides, sodium, ammonia nitrogen and nitrite nitrogen concentrations. The authors of the study have noticed a decrease in the amount of phosphates and sulphates in the water. As observed, the hydrogeochemical type of water changed from calcium-hydrogen carbonate-sulphate into calcium-sodium-hydrogen carbonate-sulphate-chloride. Changes in water chemistry are probably a result of anthropogenic impacts, and they can be associated with the transformation of land use in the catchment area, i.e. the ongoing urbanization of the area. KEY WORDS: Różany Strumień; urban catchment; water quality indicators; hydrochemistry
\end{abstract}

Corresponding author's e-mail address: okonska@amu.edu.pl

\section{Introduction}

Changes in spatial land use in the catchment area often cause changes in water circulation, but also changes in physical and chemical properties of water. Watercourses in urbanized catchments, especially in large cities, have become recipients of contaminated surface runoff and underground tributaries (Wysocka-Czubaszek, Wojno 2014). Major ions concentration in the natural chemical composition of water hardly ever changes. In urbanized catchments, water quality - influenced by a number of factors and dependent, among other things, on human activity - may be subject to significant changes within a short period of time (Molenda 2010).

In this study, the authors have conducted a variability analysis of selected physical and chemical properties of surface waters within the anthropogenically-induced catchment of the Różany Strumień. For this purpose highly dispersed, archival data on the chemistry of surface waters were collected. The literature data and the authors' own research findings cover the period 1988-2012. The evaluation of empirical data collected over twenty-five years of research could indicate the direction of hydrochemical changes occurring in surface waters in the Różany Strumień catchment and help estimate how big 
the impact of human impact in terms of water chemistry is. Moreover, these collected materials may be used as a reference base for measurements conducted since November 2015 under the Integrated Environmental Monitoring by the Różany Strumień Base Station.

\section{A description of the study area}

The Różany Strumień (Różany Potok, following the Atlas... 2005) is a left bank tributary of the River Warta. The Różany Strumień catchment is located in the north of Poznan (Fig. 1). The catchment area, bordered mostly by a watershed of the third rank, is approximately 7.5 square kilometres. According to earlier works, the catchment area was larger, and covered 12.5 square kilometres (Dzwoniarski 1988 following Choiński et al. 1995). A reduction in the area was due to a cut-off of the southern part of the catchment by a railway embankment, and due to the exclusion of the north-eastern part of the area as a result of the development of a sewer system. The network of watercourses within the catchment is seasonal, except for the Różany Strumien (RS). In the area of research, there are some small water reservoirs, the largest of which is Lake Umultowskie (LU). The bathymetric map and morphometric parameters of Lake Umultowskie can be found in the publication of Jańczak and Sziwa (1995). According to the literature data,

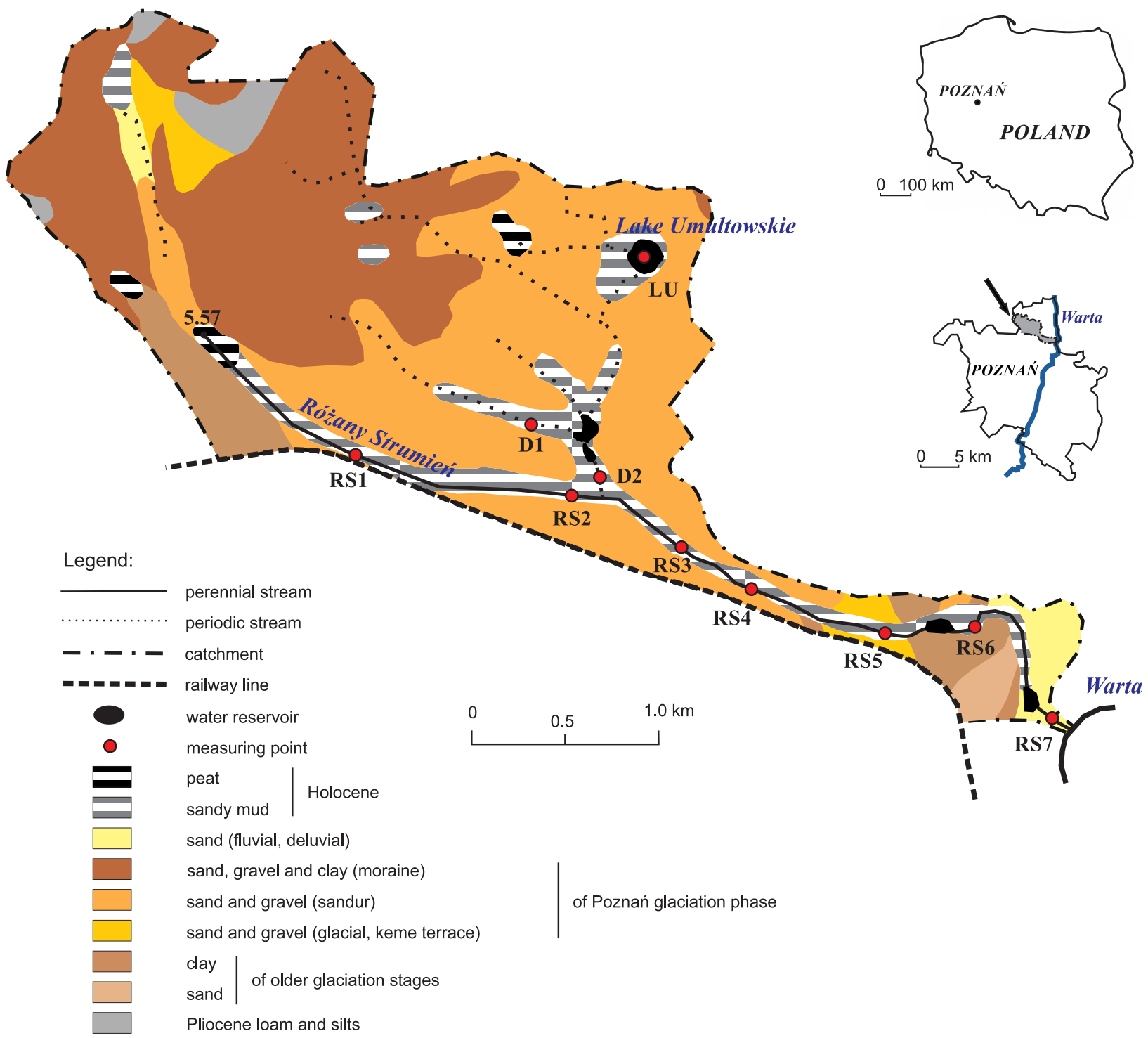

Fig. 1. The Różany Strumień catchment (hydrography based on the Atlas... 2005 and hydrographic plotting, geology following Szczegółowa Mapa... 1996). 

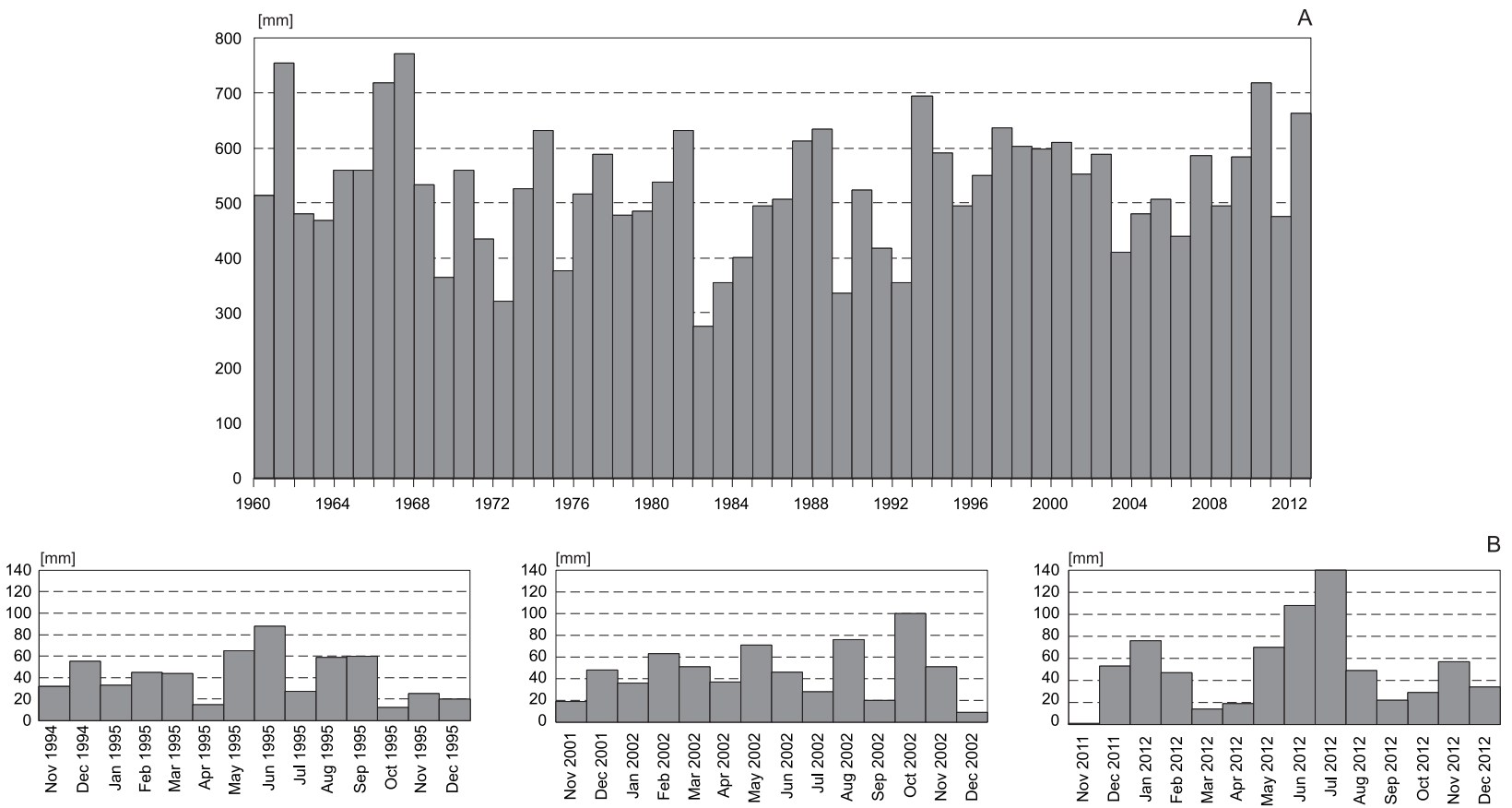

Fig. 2. Annual precipitation in Poznań region in the years 1960-2012 (A). Monthly precipitation in the years 1995, 2002 and 2012 (B) (following Rocznik... 2003, 2009, 2011, 2013).

the lake area is decreasing: it used to be 3.1 ha in 1975 (Choiński 2006), 3.0 ha in 1992 (Jańczak, Sziwa 1995), and 2.9 ha in 2000 (Kowalik 2005). The remaining reservoirs in the catchment are as follows: two retention ponds located south of Lake Umultowskie, fish ponds located in the lower reaches of the Różany Strumień in the area of The Różany Mill (RS6), and an artificial retention reservoir in the area of the watercourse estuary to the River Warta (RS7).

The area of research is distinguished by young glacial landforms shaped within the Poznan phase of the Baltic ice age. In the west of the catchment, there are hills and knolls of a terminal moraine; with clay being a dominant surface formation (Fig. 1). Central part of the catchment is occupied by the sandur plain (Naramowicki Sandur) composed of arenaceous-gravelly formations. Within the catchment, field denivelation between the Góra Moraska peak and the Różany Strumień estuary amounts to over 100 m, which gives an average downslope of $16 \%$. The River Warta valley constitutes a drainage base for both surface and ground waters.

Within the catchment, average precipitation oscillates between $500 \mathrm{~mm}$ and $550 \mathrm{~mm}$. According to the Institute of Meteorology and Water Management (IMGW), average annual precipitation in the area of Poznań (Poznań-Ławica workstation) in the period 1960-2012 amounted to $528 \mathrm{~mm}$ (Rocznik... 2003, 2009, 2011, 2013). Between 1960 and 1987, the figure stood at 516 $\mathrm{mm}$, and $542 \mathrm{~mm}$ between 1988 and 2012 (Fig. 2).

The flow rates recorded in the Różany Strumien vary along the river course (Fig. 3). According to Kowalczak (1989), in the lower reaches of the Różany Strumień, the average flow rate in 1989 amounted to approximately $0.030 \mathrm{~m}^{3} \cdot \mathrm{s}^{-1}: 0.055 \mathrm{~m}^{3} \cdot \mathrm{s}^{-1}$ in the winter half-year, and $0.022 \mathrm{~m}^{3} \cdot \mathrm{s}^{-1}$ in the summer half-year. Flow rate values measured in 1995 (Choiński et al. 1995) amounted to approximately $0.047 \mathrm{~m}^{3} \cdot \mathrm{s}^{-1}$ in the winter half-year. In 2002, between December 2001 and October 2002 (Bazyly 2003), the average flow rate was approximately $0.048 \mathrm{~m}^{3} \cdot \mathrm{s}^{-1}: 0.073$ $\mathrm{m}^{3} \cdot \mathrm{s}^{-1}$ in the winter half-year, and $0.027 \mathrm{dm}^{3} \cdot \mathrm{s}^{-1}$ in the summer half-year. Following discharge hydrograph readings, it is possible to distinguish a period of the spring and winter raised water stage and the summer months' low flow period.

According to measurements made in May 1993, and between December 1994 and June 1995, unitary runoff in the lower reaches of the Różany Strumień varied from 1.5 to $7.5 \mathrm{dm}^{3} \cdot \mathrm{s}^{-1} \cdot \mathrm{km}^{-2}$ (Choiński et al. 1995). In January 2012 and January 2013, the researchers analysed the unitary runoff structure for the catchment in winter (Andrzejak et al. 2013). Different runoff conditions in those 


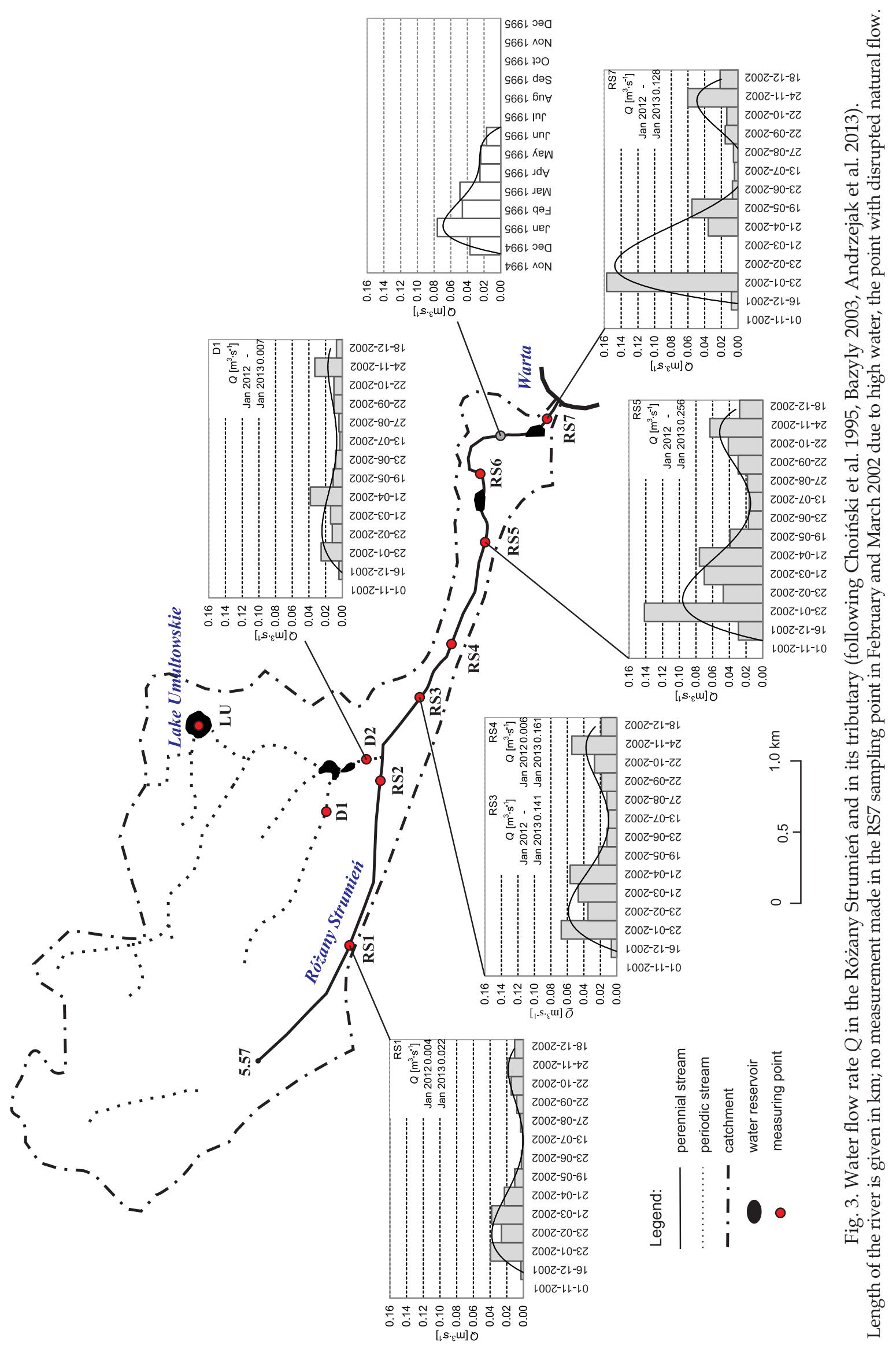




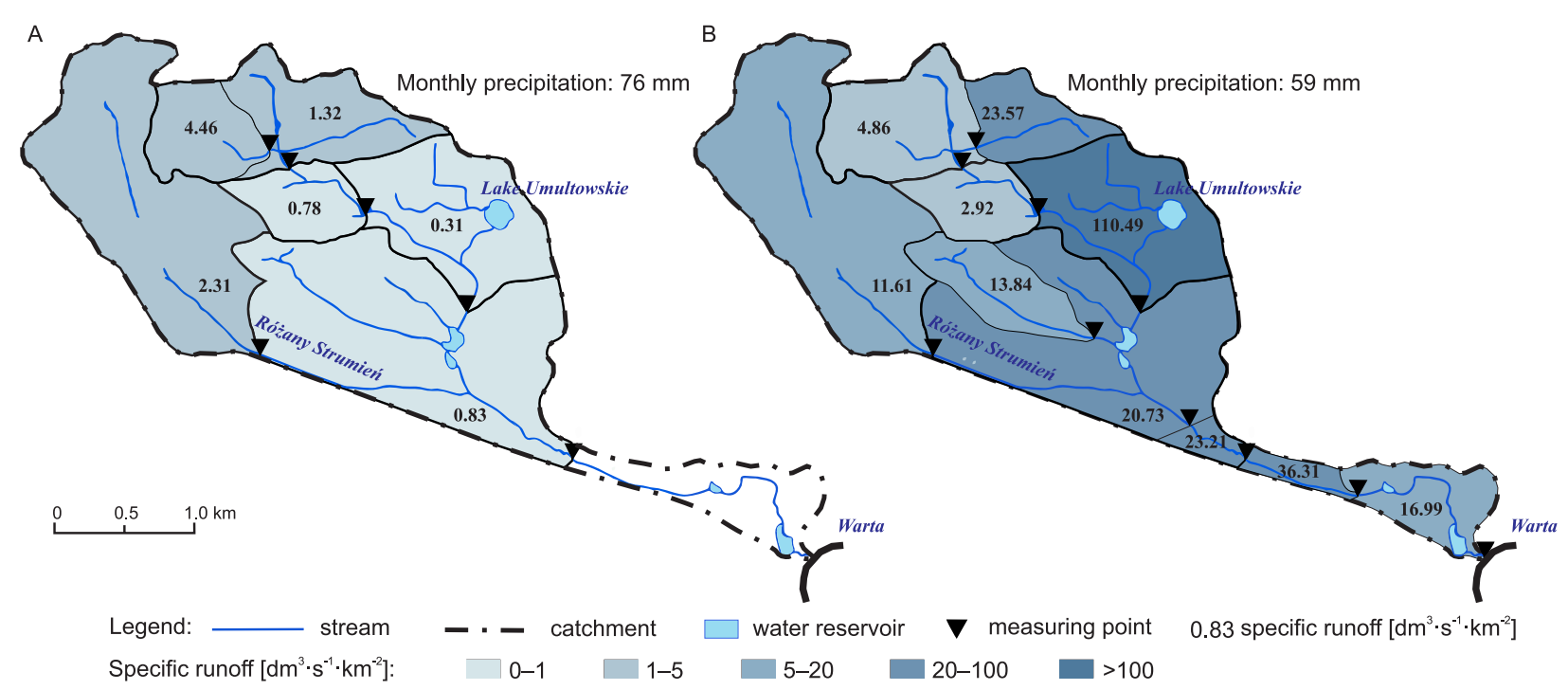

Fig. 4. Specific runoff from partial catchments of the Różany Strumień in January 2012 (A) and in January 2013 (B) (following Andrzejak et al. 2013; precipitation from Rocznik... 2013).

two periods imply a great variety of water affluence and hydrogeological activity in the Różany Strumień partial catchments (Fig. 4).

Agricultural land prevails in the structure of land development within the catchment. The central part of the catchment is built-up with housing and services investments and a complex of university premises. The extension of Adam Mickiewicz University campus (at the beginning of the 21st century) and new housing investments resulted in enlarging the proofed area within the drainage basin. It is estimated that, in the years from 1992 to 2012, the proportion of such areas increased from about $5 \%$ to $16 \%$. In the future, the figure may even reach $20 \%$ (Sojka et al. 2014). Figure 5 presents changes in the structure of environmental development in the catchment, which occurred over a period of ten years.

A crucial issue in terms of water circulation within the catchment is the methodology of draining off rainwater from built-up areas. Rainwater is collected by either retention ponds or the Różany Strumien, or drained beyond the catchment by means of a sewerage system. Thereby, the duration of water detention within the catchment is shortened or water balance losses occur, respectively. Significant downslopes of the west part of the catchment and poorly permeable formations covering the area are not conductive to rainfall infiltration or water retention, which results in an increased surface runoff.

\section{Methods and the source of data}

The conducted variability analysis of physical and chemical parameters of the catchment surface waters was based on 1) available archival documentary - highly dispersed and frequently issued as conference materials or reports for administrative purposes, and 2) research findings from the authors own measurements. Between 1988 and 2012, analyses of physical and chemical properties of the Różany Strumień were carried out irregularly (Table 1) with the application of different parameters. However, as most of the researchers were the academics of the Faculty of Geographical and Geological Sciences (WNGiG) of Adam Mickiewicz University in Poznań, most analyses were performed following a similar methodology as applied at the Hydrochemical Laboratory of WNGiG. In the area covered by the research there are no surface water sampling and controlling points of the countrywide network under the State Environment Monitoring Programme.

In this study, changes in the values of selected indicators were analysed in the following time periods at the following sampling points:

- from 1988 to 2012: RS3 and RS4 (approximately 400 meters distant from one another), set in the Różany Strumień,

- in 2001 and 2002: down the watercourse of the Różany Strumień, 


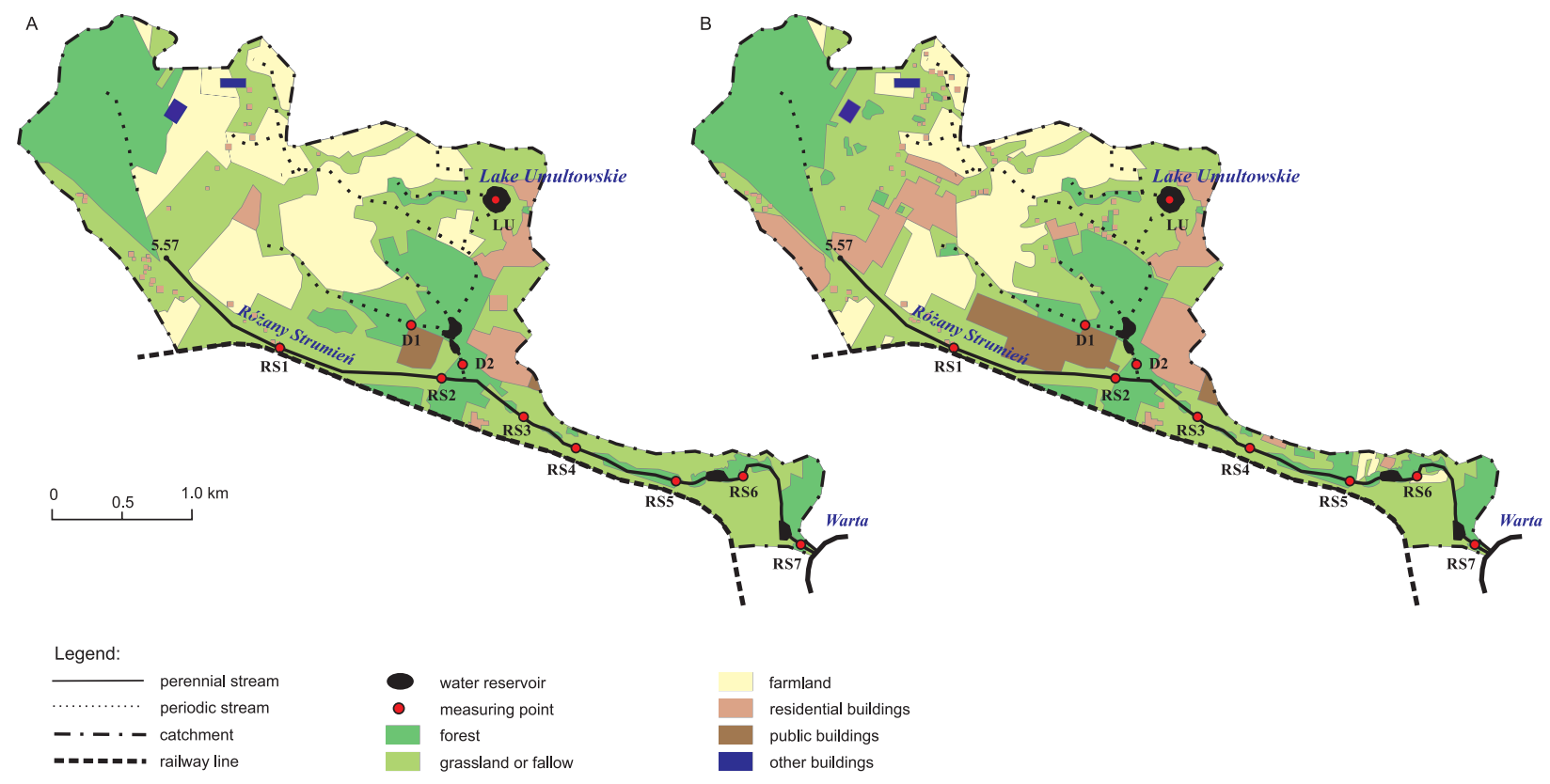

Fig. 5. Land development of the catchment in 2003 (A) and in 2013 (B) (following Mapa Sozologiczna Polski w skali 1:50000 2004, GUGiK 2016).

- in 2001 and 2006: Lake Umultowskie waters, and in 2001: the Różany Strumień tributary.

The discussed quality indicators of surface waters were divided into groups according to the Regulation of the Minister of Environment (Rozporządzenie... 2016). The determined values referred to 1) the limits provided by the Regulation (Rozporządzenie... 2016) for lowland sandy-loam river, and stratified, high calcium content lake (Rozporządzenie... 2011, Kolada et al. 2005), and 2) the average chemical composition of river water of Europe (EEA 2016).

Table 1. Specification of chemistry research carried out in surface waters in the Różany Strumień catchment.

\begin{tabular}{|c|c|c|c|c|}
\hline No & $\begin{array}{l}\text { Date of sam- } \\
\text { pling }\end{array}$ & Sampling point & $\begin{array}{l}\text { Hydrogeochemical } \\
\text { water type }\end{array}$ & Data source \\
\hline 1 & 16.12 .1988 & RS4 & $\mathrm{Ca}-\mathrm{HCO}_{3}-\mathrm{SO}_{4}$ & Choiński et al. 1993 \\
\hline 2 & 13.03.1989 & RS4 & $\mathrm{Ca}-\mathrm{Mg}-\mathrm{HCO}_{3}-\mathrm{SO}_{4}$ & Choiński et al. 1993 \\
\hline 3 & 16.06 .1989 & RS4 & $\mathrm{Ca}-\mathrm{HCO}_{3}-\mathrm{SO}_{4}$ & Choiński et al. 1993 \\
\hline 4 & 18.09.1989 & RS4 & $\mathrm{Ca}-\mathrm{HCO}_{3}-\mathrm{SO}_{4}$ & Choiński et al. 1993 \\
\hline 5 & 23.04.1993 & RS4 & $\mathrm{Ca}-\mathrm{HCO}_{3}-\mathrm{SO}_{4}$ & Choiński et al. 1993 \\
\hline 6 & 23.01 .1995 & RS4 & $\mathrm{Ca}-\mathrm{HCO}_{3}-\mathrm{SO}_{4}$ & Choiński et al. 1995 \\
\hline 7 & 27.02 .1995 & RS4 & $\mathrm{Ca}-\mathrm{HCO}_{3}-\mathrm{SO}_{4}$ & Choiński et al. 1995 \\
\hline 8 & 20.03.1995 & RS4 & $\mathrm{Ca}-\mathrm{HCO}_{3}-\mathrm{SO}_{4}$ & Choiński et al. 1995 \\
\hline 9 & 22.04 .1995 & RS4 & $\mathrm{Ca}-\mathrm{HCO}_{3}-\mathrm{SO}_{4}$ & Choiński et al. 1995 \\
\hline 10 & 18.05.1995 & RS4 & $\mathrm{Ca}-\mathrm{HCO}_{3}-\mathrm{SO}_{4}$ & Choiński et al. 1995 \\
\hline 11 & 04.06 .1995 & RS4 & $\mathrm{Ca}-\mathrm{HCO}_{3}-\mathrm{SO}_{4}$ & Choiński et al. 1995 \\
\hline 12 & 22.05.2001 & $\begin{array}{c}\text { RS1, RS2, RS4, RS5, RS6, D1, LU; } \\
\text { RS7, D2 }\end{array}$ & $\begin{array}{l}\mathrm{Ca}-\mathrm{HCO}-\mathrm{SO}_{4} \\
\mathrm{Ca}-\mathrm{Mg}-\mathrm{HCO}_{3}-\mathrm{SO}_{4}\end{array}$ & $\begin{array}{l}\text { Jackowiak et al. 2002, } \\
\text { Ziętkowiak } 2003\end{array}$ \\
\hline 13 & 26.06 .2001 & $\begin{array}{l}\text { RS2, RS3, RS4; } \\
\text { D2 }\end{array}$ & $\begin{array}{l}\mathrm{Ca}-\mathrm{HCO}_{3}-\mathrm{SO}_{4} \\
\mathrm{Ca}-\mathrm{HCO}_{3}-\mathrm{SO}_{4}-\mathrm{Cl}\end{array}$ & $\begin{array}{l}\text { Jackowiak et al. 2002, } \\
\text { Ziętkowiak } 2003\end{array}$ \\
\hline 14 & 23.06 .2002 & RS1, RS3, RS5, D2 & $\mathrm{Ca}-\mathrm{Mg}-\mathrm{HCO}_{3}-\mathrm{SO}_{4}$ & Bazyly 2003 \\
\hline 15 & 17.05.2006 & RS3 & $\mathrm{Ca}-\mathrm{HCO}_{3}-\mathrm{SO}_{4}-\mathrm{Cl}$ & Okońska, Marciniak 2009 \\
\hline 16 & 05.05 .2008 & RS3 & $\mathrm{Ca}-\mathrm{HCO}_{3}-\mathrm{SO}_{4}$ & Okońska, Marciniak 2009 \\
\hline 17 & 20.10 .2009 & RS3 & $\mathrm{Ca}-\mathrm{HCO}_{3}-\mathrm{SO}_{4}-\mathrm{Cl}$ & Okońska, unpublished \\
\hline 18 & 13.06.2011 & RS3 & $\mathrm{Ca}-\mathrm{HCO}_{3}-\mathrm{SO}_{4}-\mathrm{Cl}$ & Okońska, unpublished \\
\hline 19 & 29.09 .2012 & RS3 & $\mathrm{Ca}-\mathrm{Na}-\mathrm{HCO}_{3}-\mathrm{SO}_{4}-\mathrm{Cl}$ & Okońska, unpublished \\
\hline
\end{tabular}


The average values were calculated as the mean of distribution series $\bar{x}$, according to:

$$
\bar{x}=\frac{1}{n} \sum_{i=1}^{k} \bar{x}_{i} \cdot n_{i}
$$

where $k$ stands for class, $n_{i}-i$-class quantity, $\bar{x}_{i}$ - the $i$-class mean and $n$ - total number of observations. Due to the lack of continuity in the measurement of water flow in the stream, the authors were not able to convert the concentration of substances to the loads.

In this paper, the authors quote the trophic state indicators TSI of Lake Umultowskie by Carlson (1977), calculated by Klimaszyk (2006).

Following the classification of Altowski and Szwiec (Pazdro, Kozerski 1990), a hydrogeochemical type was determined for each analysis.

\section{Research findings}

\section{The indicators of physical properties}

The indicators relating to the physical properties of surface waters include temperature and total suspended solids (TSS).

In the years 1988-2012, the variability of the temperature range of the Różany Strumien oscillated from $4.0^{\circ} \mathrm{C}$ to $17.6^{\circ} \mathrm{C}$ (Fig. 6) Water temperature of Lake Umultowskie reached the maximum recorded level of $22^{\circ} \mathrm{C}$. Determined values of the TSS index varied from 0 to $109 \mathrm{mg} \cdot \mathrm{dm}^{-3}$ in the Różany Strumień and from 10 to $17 \mathrm{mg} \cdot \mathrm{dm}^{-3}$

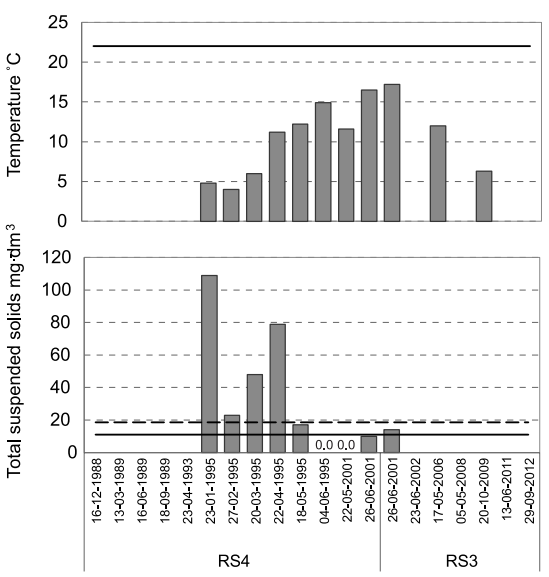

in the Różany Strumień tributary and Lake Umultowskie.

Values of temperature remain under limit value for quality class I (Rozporządzenie... 2016). As for the TSS, in several cases the research shows a significant overrun of the limit value of quality class II.

\section{The indicators of oxygen conditions}

Oxygenation, dissolved oxygen, biochemical oxygen demand $\left(\mathrm{BOD}_{5}\right)$ and chemical oxygen demand (COD-Mn) are among the indicators of oxygen conditions.

The oxygenation in the Różany Strumień and its tributary was analysed in 2001 only (Fig. 7). The determined values ranged from $81.6 \%$ to $108.0 \%$. In Lake Umultowskie research was also carried out in 2006. It was found that oxygenation reached 103.5\% in 2001 and 104.9\% in 2006.

In the Różany Strumien and its tributary, the concentrations of dissolved oxygen met class I condition of water quality for nearly the whole of the observation period. The concentrations were within the limits range of 7.0 to $12.0 \mathrm{mgO}_{2} \cdot \mathrm{dm}^{-3}$. Only once, in 2002, the concentration of oxygen in the major watercourse of the catchment dropped to $6.1 \mathrm{mgO}_{2} \cdot \mathrm{dm}^{-3}$ (too low a concentration to be classified as class II).

The thermal and oxygen profile study of Lake Umultowskie (Fig. 8), carried out in the summer of 1992, implied the lake's slight stratification and reduction in the concentration of oxygen in the water below the depth of $2 \mathrm{~m}$ (Jańczak, Sziwa

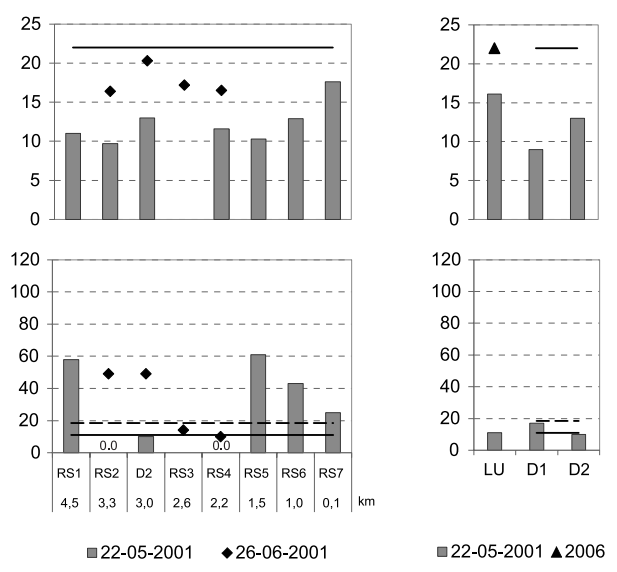

Fig. 6. Physical indicators of surface waters: temperature and total suspended solids. Explanation: A - Różany Strumień (1988-2012); B - downstream of the Różany Strumień - kilometres from the estuary (2001); C - Lake Umultowskie $(2001,2006)$ and Różany Strumień tributary (2001); solid line - limit value for class I; dotted line - limit value for class II (according to Rozporządzenie...2016). 

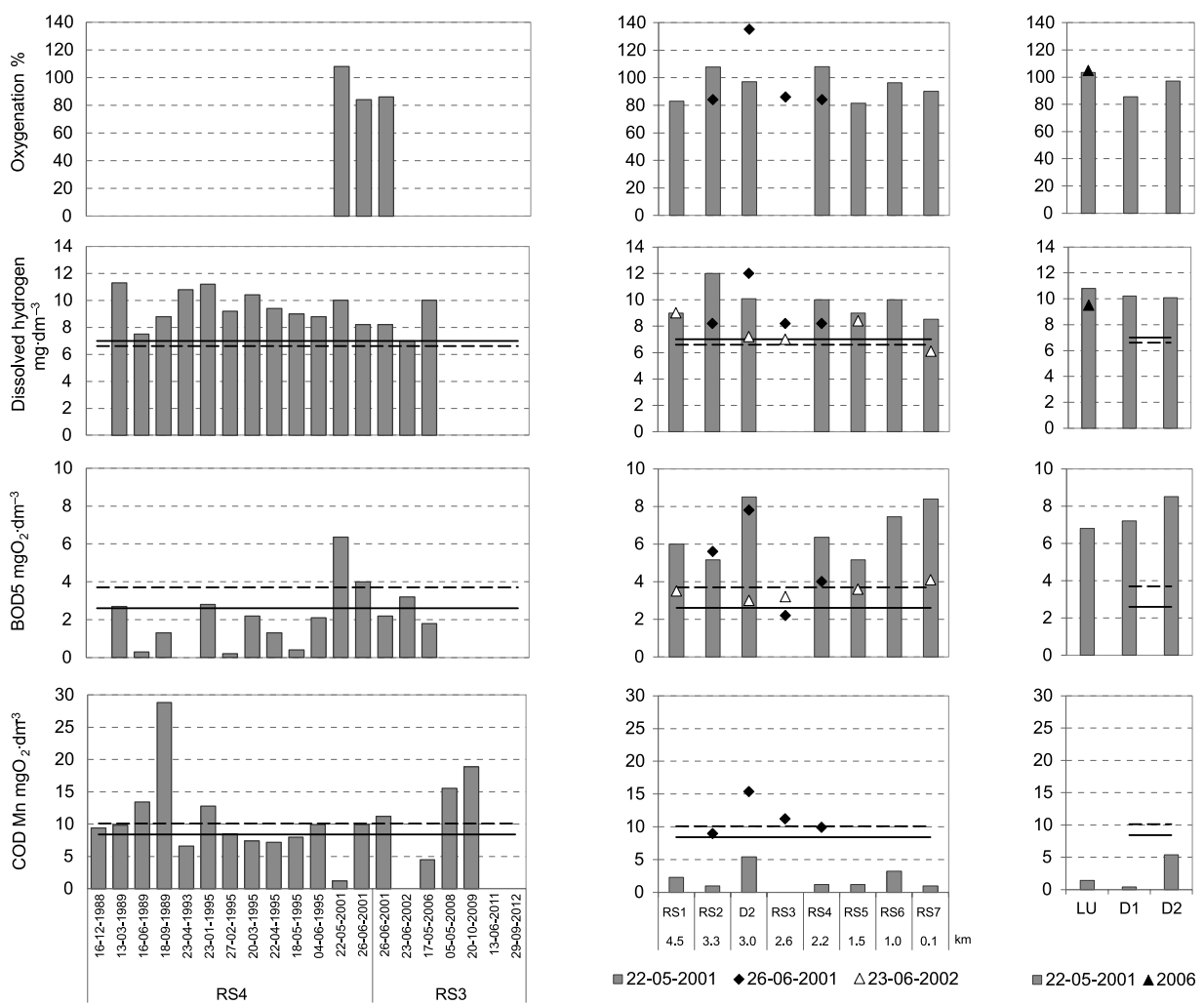

Fig. 7. Oxygen indicators of surface waters: oxygenation, dissolved oxygen, biochemical oxygen demand $\left(\mathrm{BOD}_{5}\right)$ and chemical oxygen demand (COD-Mn).

Explanation: A - Różany Strumień (1988-2012); B - downstream of the Różany Strumień - kilometres from the estuary (2001, 2002); C - Lake Umultowskie $(2001,2006)$ and Różany Strumień tributary (2001); solid line - minimum/

limit value for class I; dotted line - minimum/limit value for class II (according to Rozporządzenie...2016).

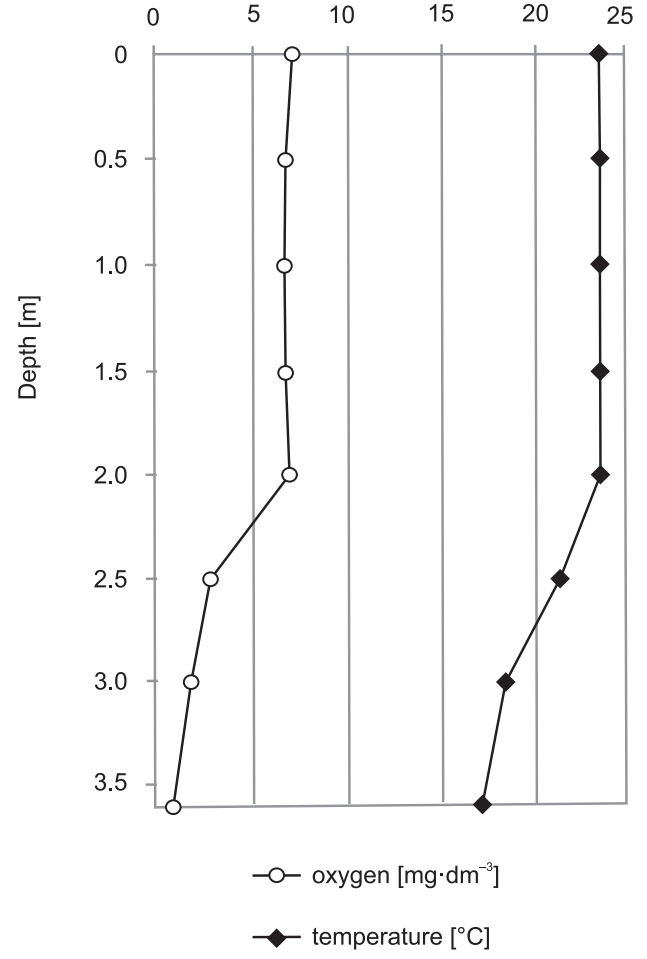

Fig. 8. Thermal and oxygen profile of Lake Umultowskie (13.08.1992; Jańczak, Sziwa 1995).
1995). The oxygen content is $<4 \mathrm{mg} \cdot \mathrm{dm}^{-3}$ at the depth of $2.5 \mathrm{~m}$.

With regard to $\mathrm{BOD}_{5}$, the variability range of the parameter values in the surface waters of the analysed catchment oscillated between 0.2 and $8.5 \mathrm{mgO}_{2} \cdot \mathrm{dm}^{-3}$ (Fig. 7). At first, the indicator values were generally within the specification of quality class I; however, since 2001, the values of $\mathrm{BOD}_{5}$ increased, and even exceeded the limit value of quality class II.

In the years 1998-2012, COD-Mn values varied from 0.4 to $28.8 \mathrm{mgO}_{2} \cdot \mathrm{dm}^{-3}$. Low concentrations occurred in May of 2001 and 2006 only. The indicator showed upper values, near the limit for water quality class I and II, for most of the observation period, exceeding the limit value for class II a few times.

\section{The indicators of water salinity}

The indicators of water salinity include general indicators such as conductivity, dissolved substances, hardness and the following ions: 

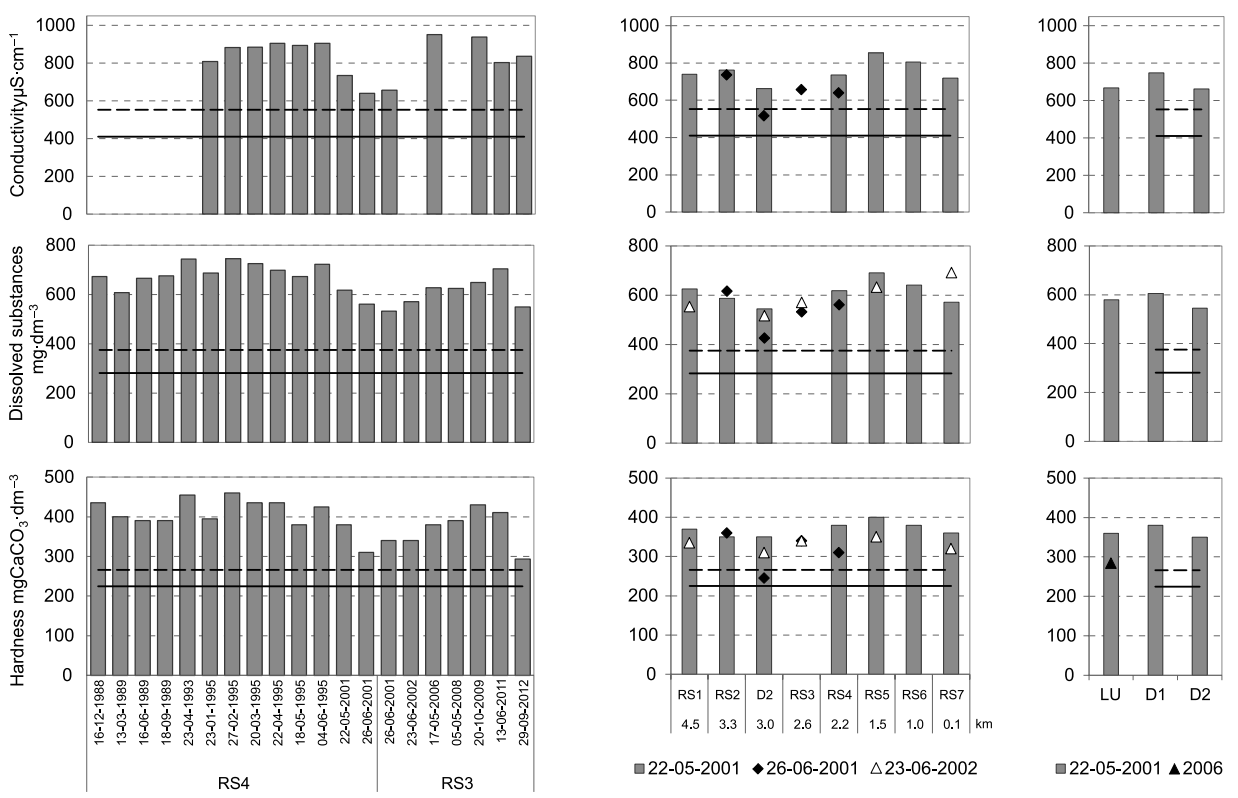

Fig. 9. General indicators of water salinity: conductivity, dissolved substances and hardness.

Explanation: A - Różany Strumień (1988-2012); B - downstream of the Różany Strumien - kilometres from the estuary $(2001,2002)$; C - Lake Umultowskie $(2001,2006)$ and Różany Strumień tributary $(2001)$; solid line - limit value for class I; dotted line - limit value for class II (according to Rozporządzenie...2016).

sulphates, chlorides, calcium, magnesium. These ions, plus sodium, potassium and hydrogen carbonate, belong to the major type of surface water ions and make up a hydrogeochemical type of water.

The analysed surface waters were characterized by conductivity oscillating between 640 and $951 \mu \cdot \mathrm{Scm}^{-1}$, dissolved substances - between 519 and $735 \mathrm{mg} \cdot \mathrm{dm}^{-3}$, and hardness ranging from 284 to $460 \mathrm{mgCaCO} \cdot \mathrm{dm}^{-3}$. The observed indicators values in all the stream water samples exceeded the limit value of class II (Fig. 9). The condition of I-II class for lake water $\left(\leq 800 \mu \cdot \mathrm{Scm}^{-1}\right)$ was met for the conductivity parameters.

In the years 1988-2012, sulphates ranged from 82.1 to $192.9 \mathrm{mgSO}_{4} \cdot \mathrm{dm}^{-3}$ (Fig. 10), with chlorides ranging from 23.4 to $64.2 \mathrm{mgCl} \cdot \mathrm{dm}^{-3}$. Both parameter values exceeded the limit value of class II. Sulphate concentrations decreased, whereas in recent years chloride values obtained the highest concentrations. Hydrogen carbonate and carbonate are displayed jointly in the chart. In the analysed water samples, the value range of hydrogen carbonate oscillated between 200.1 and $335.6 \mathrm{mgHCO}_{3} \cdot \mathrm{dm}^{-3}$, whereas the carbonate value range varied from 0.0 to $26.4 \mathrm{mgCO}_{3} \cdot \mathrm{dm}^{-3}$. Calcium ranged from 86.0 to $168.0 \mathrm{mgCa} \cdot \mathrm{dm}^{-3}$ (quality class below class II), magnesium from 0 to $34.8 \mathrm{mgMg} \cdot \mathrm{dm}^{-3}$ (quality class I and above class II). As for sodium, its concentrations varied between 10.0 and $38.3 \mathrm{mgNa} \cdot \mathrm{dm}^{-3}$ (with the highest concentration value in the last year of the analysis period). The concentration of potassium rose from 1.3 to $5.7 \mathrm{mgK} \cdot \mathrm{dm}^{-3}$.

The determined hydrogeochemical type of water based on major ions is provided in Table 1. It led us to conclude that the surface water of the analysed catchment was of a calcium hydrogen carbonate and sulphate type $\left(\mathrm{Ca}-\mathrm{HCO}_{3}-\mathrm{SO}_{4}\right)$ and, seasonally, of a calcium magnesium hydrogen carbonate and sulphate type ( $\left.\mathrm{Ca}-\mathrm{Mg}-\mathrm{HCO}_{3}-\mathrm{SO}_{4}\right)$. In the final years of the analysed period, the type of water changed into calcium hydrogen carbonate, sulphate and chloride (Ca- $\left.\mathrm{HCO}_{3}-\mathrm{SO}_{4}-\mathrm{Cl}\right)$. In 2012 the hydro chemical water type was significantly marked by sodium and chloride ions (Ca-Na- $-\mathrm{HCO}_{3}-\mathrm{SO}_{4}-\mathrm{Cl}$ ).

\section{The indicators of acidification}

Acidity, $\mathrm{pH}$ reaction and alkalinity are among the indicators of acidification.

In the analysed water samples, water acidity degree, resulting from carbon dioxide occurrence, varied from 0.00 to $0.31 \mathrm{mval} \cdot \mathrm{dm}^{-3}$ (Fig. 11). Values of $\mathrm{pH}$ reaction stood between 6.6 and 8.4, while the value range of class II was 6.7-8.1. It was found that alkalinity was $185.2-275.3 \mathrm{mgCaCO} \cdot \mathrm{dm}^{-3}$, 

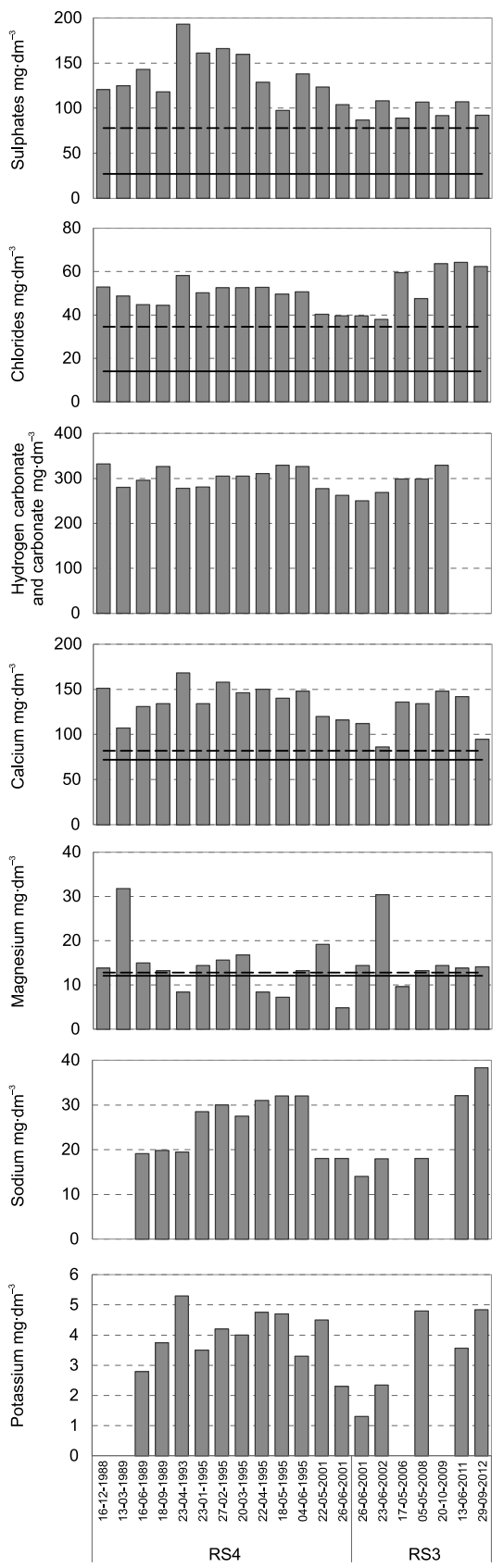
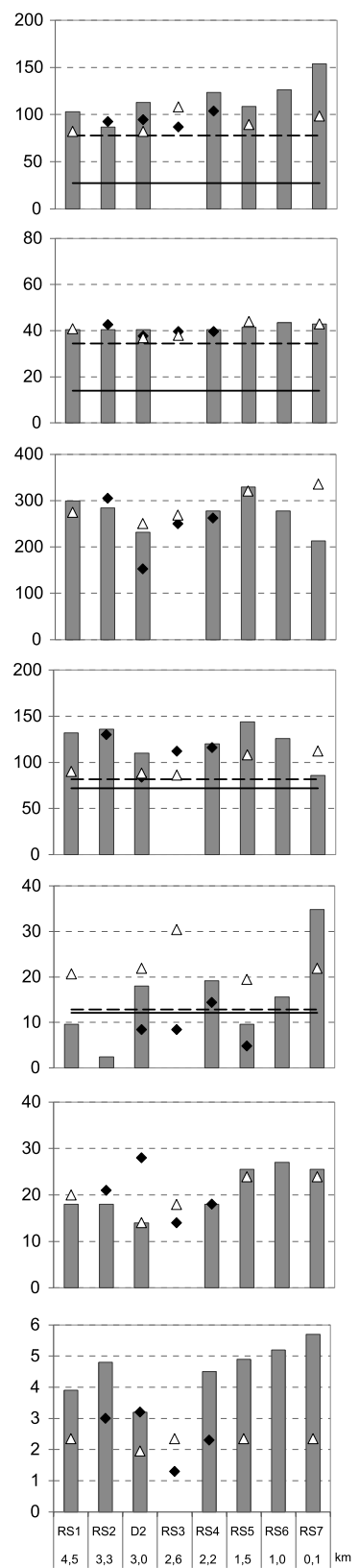

$\square 22-05-2001 \bullet 26-06-2001 \triangle 23-06-2002$
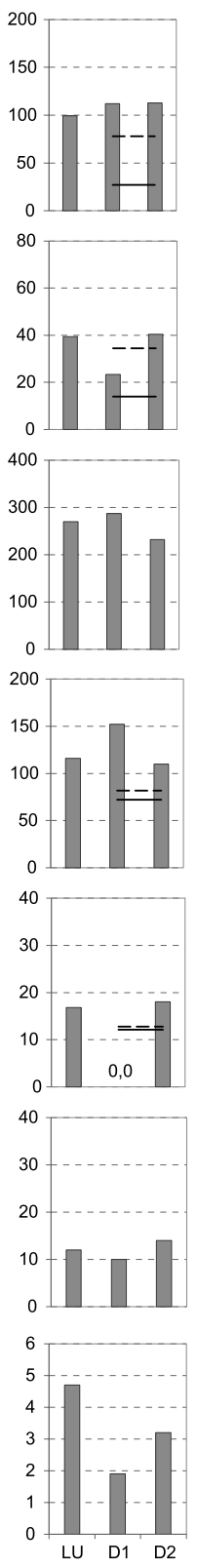

$\square 22-05-2001$

Fig. 10. Major ions: sulphates, chlorides, hydrogen carbonate with carbonate, calcium, magnesium, sodium and potassium.

Explanation: A - Różany Strumień (1988-2012); B - downstream of the Różany Strumień - kilometres from the estuary $(2001,2002)$; C - Lake Umultowskie and Różany Strumień tributary (2001); solid line - limit value for class I; dotted line - limit value for class II (according to Rozporządzenie...2016).

without exceeding the limit value for class II $(\leq 205$ $\mathrm{mgCaCO}_{3} \cdot \mathrm{dm}^{-3}$ ) three times only.

\section{The indicators of biogenic conditions}

Phosphates phosphorus, total phosphorus, ammonia nitrogen, nitrite nitrogen and nitrate nitrogen are among the indicators of biogenic conditions.
In the Różany Strumień, the researchers determined the occurrence of the following indicator concentrations: phosphates phosphorus within the value range from 0.00 to 0.11 $\mathrm{mgP}-\mathrm{PO}_{4} \cdot \mathrm{dm}^{-3}$, total phosphorus from 0.01 to $0,14 \mathrm{mgP} \cdot \mathrm{dm}^{-3}$, ammonia nitrogen from 0,00 to $0,99 \mathrm{mgN}-\mathrm{NH}_{4} \cdot \mathrm{dm}^{-3}$, nitrite nitrogen from 0.00 to $0.12 \mathrm{mgN}-\mathrm{NO}_{2} \cdot \mathrm{dm}^{-3}$, and nitrate nitrogen from 0.08 to $3.54 \mathrm{mgN}-\mathrm{NO}_{3} \cdot \mathrm{dm}^{-3}$ (Fig. 12). 

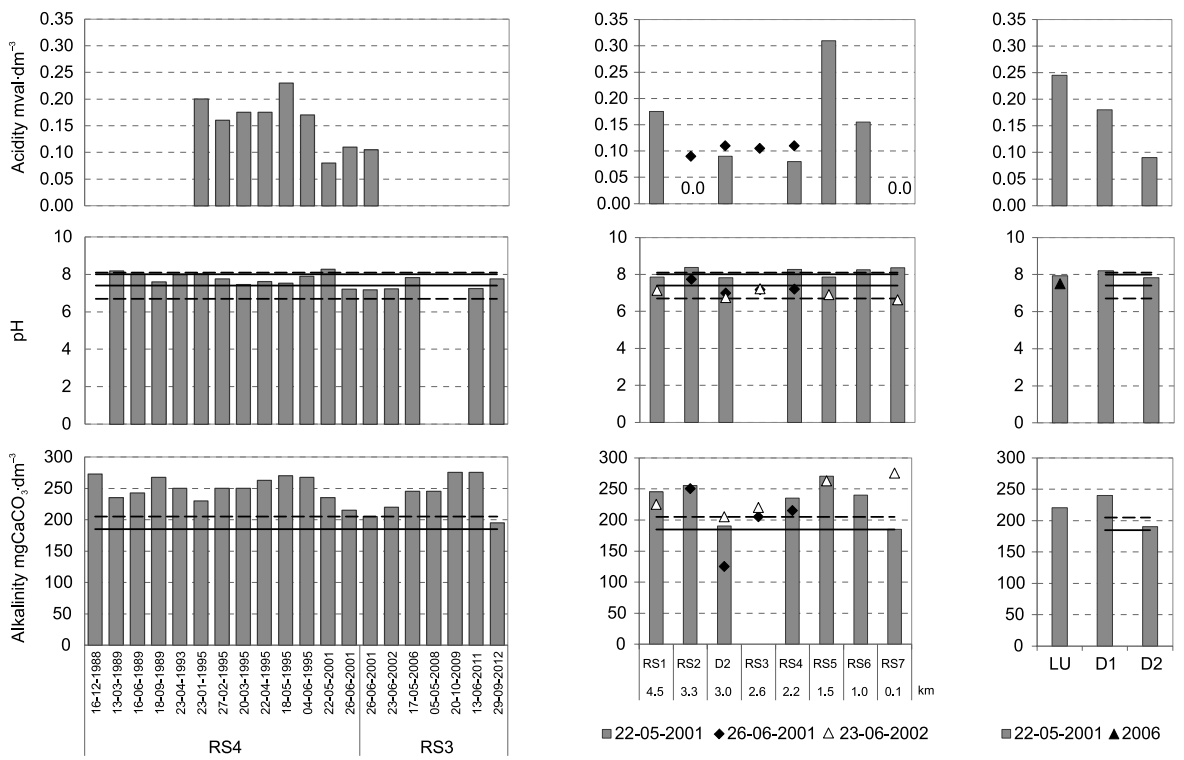

Fig. 11. Indicators of acidification: acidity, $\mathrm{pH}$ reaction and alkalinity.

Explanation: A - Różany Strumień (1988-2012); B - downstream of the Różany Strumień - kilometres from the estuary (2001, 2002); C - Lake Umultowskie $(2001$, 2006) and Różany Strumień tributary (2001); solid line - range/limit value for class I; dotted line - range/limit value for class II (according to Rozporządzenie...2016).
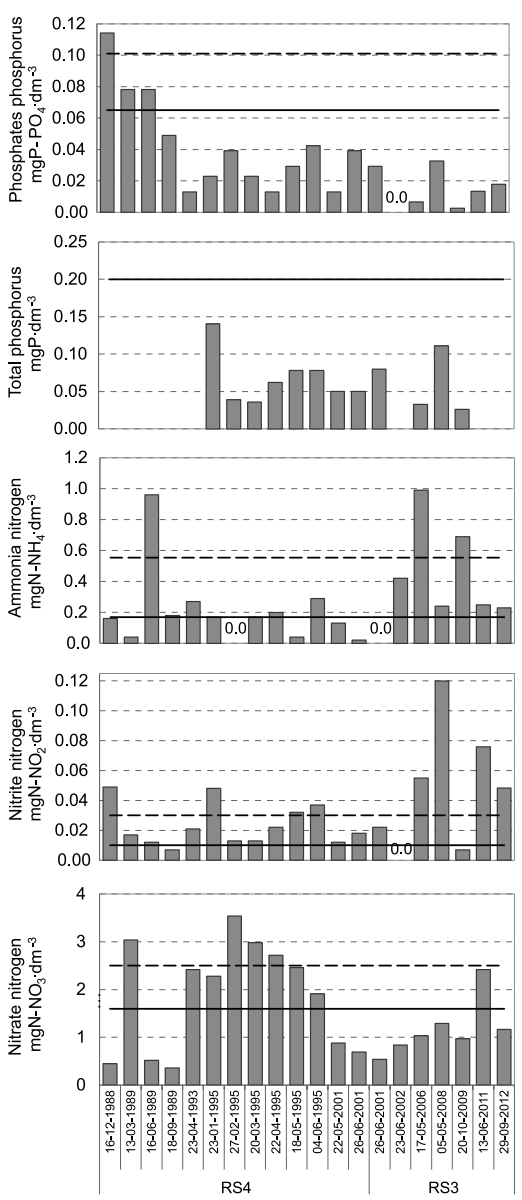
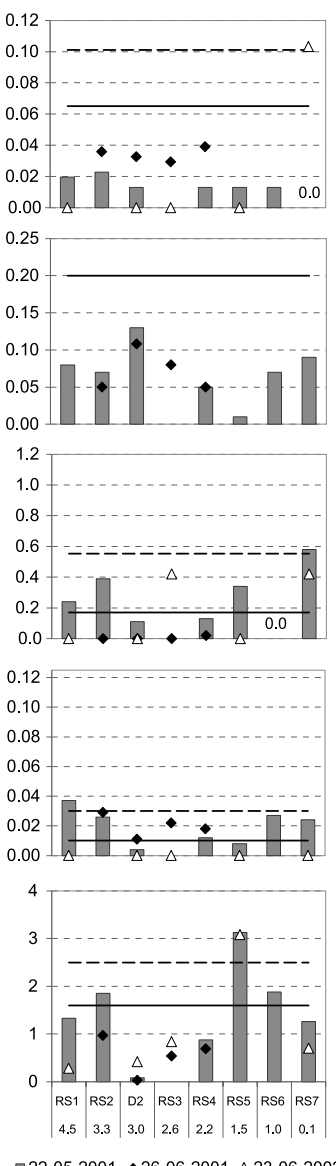

$\square 22-05-2001 \bullet 26-06-2001 \triangle 23-06-2002$
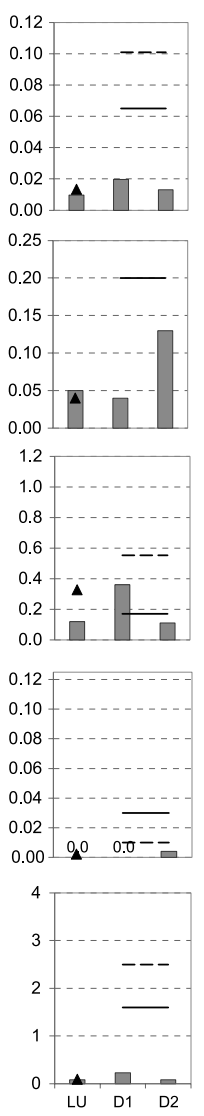

$\square 22-05-2001 \Delta 2006$

Fig. 12. Indicators of biogenic conditions: phosphates phosphorus, total phosphorus, ammonia nitrogen, nitrite nitrogen and nitrate nitrogen.

Explanation: A - Różany Strumień (1988-2012); B - downstream of the Różany Strumień - kilometres from the estuary $(2001,2002)$; C - Lake Umultowskie $(2001,2006)$ and Różany Strumień tributary (2001); solid line - limit value for class I; dotted line - limit value for class II (according to Rozporządzenie...2016). 
In all the analysed samples of stream water, total phosphorus concentrations indicated quality class I. The values of total phosphorus determined for lake water classified the indicator to quality class II in 2001 and quality class I in 2006.

With regard to phosphates phosphorus, the earliest analyses showed phosphates phosphorus occurrence characteristic of quality class II or lower. Ever since the beginning of the 1990's, phosphates phosphorus occurrence in the water has complied with the highest quality class. At different times, the concentrations of nitrogen compounds in the analysed samples exceeded the limit values for quality class I and II. High concentrations of ammonia nitrogen and nitrite
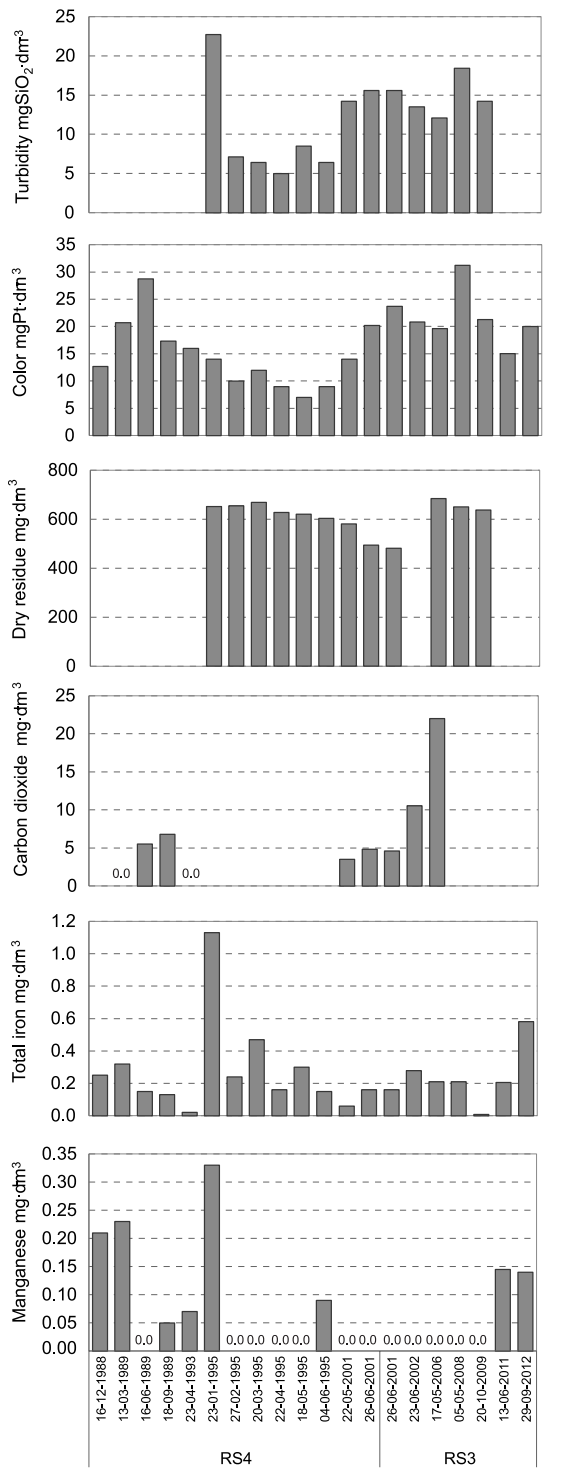

nitrogen in surface waters occurred in recent years in particular, whereas the concentrations of nitrate nitrogen reached high values back in the 1990's.

\section{Additional quality indicators and heavy metals}

During the research of surface waters of the Różany Strumień catchment, additional physical and chemical parameters were analysed, such as: turbidity, colour, dry residue, carbon dioxide, iron and manganese. Concentration changes in the parameters are presented in Figure 13. For the indicators enumerated above no limit values are
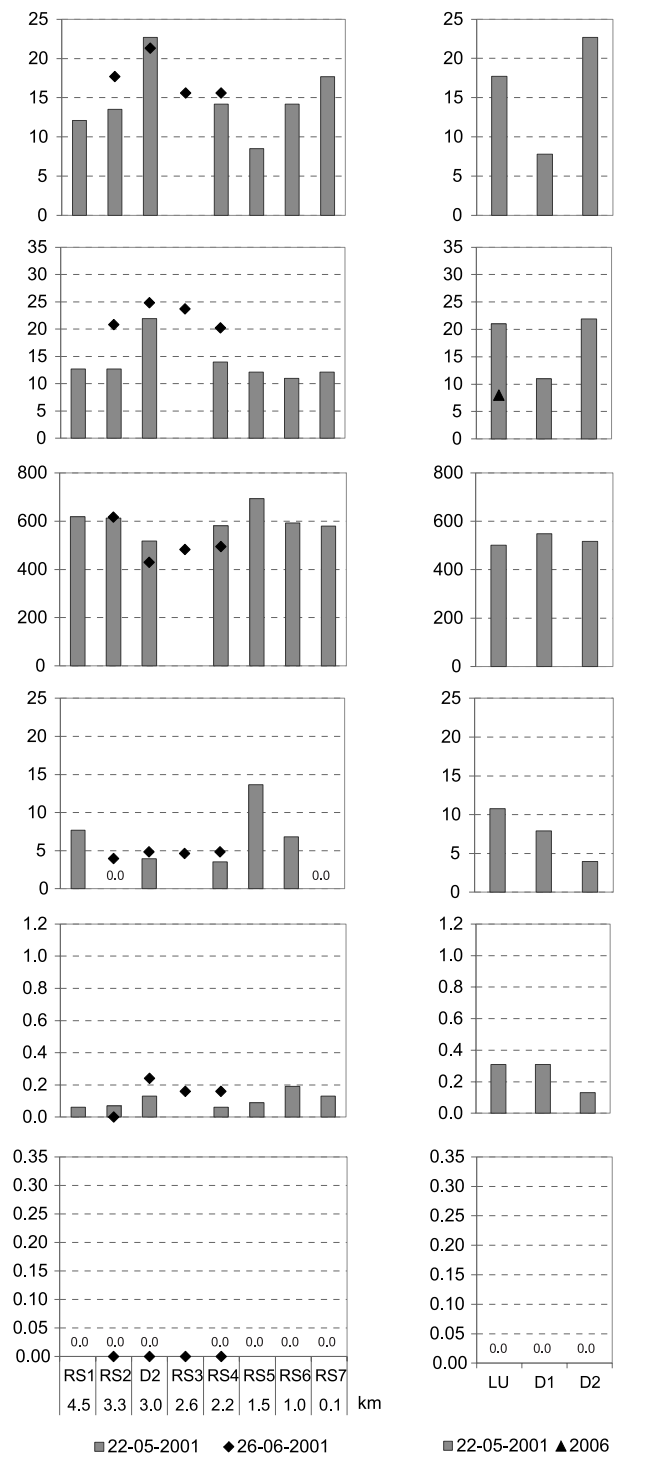

Fig. 13. Additional quality indicators: turbidity, color, dry residue, carbon dioxide, total iron and manganese. Explanation: A - Różany Strumień (1988-2012); B - downstream of the Różany Strumień - kilometres from the estuary (2001); C - Lake Umultowskie $(2001,2006)$ and Różany Strumień tributary (2001). 
Table 2. Heavy metal, fluoride and bromide concentrations in the Różany Strumień.

\begin{tabular}{|l|c|c|c|c|}
\hline \multirow{2}{*}{\multicolumn{1}{c|}{ Parameter }} & \multirow{2}{*}{ Unit } & \multicolumn{2}{c|}{ RS3 sampling point } & \multirow{2}{*}{$\begin{array}{c}\text { Limit value of } \\
\text { class I-II* }\end{array}$} \\
\cline { 2 - 4 } & & 13.06 .2011 & 29.09 .2012 & - \\
\hline Lead $(\mathrm{Pb})$ & $\mathrm{mg} \cdot \mathrm{dm}^{-3}$ & 0.00105 & 0.00198 & $\leq 0.05$ \\
\hline Copper $(\mathrm{Cu})$ & $\mathrm{mg} \cdot \mathrm{dm}^{-3}$ & 0.00200 & 0.00300 & $\leq 1.00$ \\
\hline Zinc $(\mathrm{Zn})$ & $\mathrm{mg} \cdot \mathrm{dm}^{-3}$ & 0.02000 & 0.02500 & - \\
\hline Cadmium $(\mathrm{Cd})$ & $\mathrm{mg} \cdot \mathrm{dm}^{-3}$ & 0.00700 & 0.00800 & - \\
\hline Nickel $(\mathrm{Ni})$ & $\mathrm{mg} \cdot \mathrm{dm}^{-3}$ & 0.00600 & 0.00500 & $\leq 0.02$ \\
\hline Chromium $\left(\mathrm{Cr}^{6+}\right)$ & $\mathrm{mg} \cdot \mathrm{dm}^{-3}$ & 0.00096 & 0.00145 & $\leq 1.50$ \\
\hline Fluorides $(\mathrm{F})$ & $\mathrm{mg} \cdot \mathrm{dm}^{-3}$ & 0.24200 & 0.21000 & - \\
\hline Bromides $(\mathrm{Br})$ & $\mathrm{mg} \cdot \mathrm{dm}^{-3}$ & 0.25500 & 0.08500 & \\
\hline
\end{tabular}

Explanation: * - following Rozporządzenie... 2016.

Table 3. Trophic state index TSI (following Carlson 1977) of Lake Umultowskie (Klimaszyk 2006).

\begin{tabular}{|l|c|c|c|c|}
\hline \multicolumn{1}{|c|}{ Indicator } & Unit & Value & Index & Value \\
\hline Transparency (Secchi depth) & $\mathrm{m}$ & 2.00 & TSI SD & 50.0 \\
\hline Total phosphorus & $\mathrm{mgP} \cdot \mathrm{dm}^{-3}$ & 0.04 & TSI TP & 57.5 \\
\hline Chlorophyll $a$ & $\mu \mathrm{g} \cdot \mathrm{dm}^{-3}$ & 24.6 & TSI Chl & 62.0 \\
\hline
\end{tabular}

provided by the Regulation (Rozporządzenie... 2016).

In the analysed waters, turbidity and colour were determined within the limits from 5.0 to $22.7 \mathrm{mgSiO}_{2} \cdot \mathrm{dm}^{-3}$ and from 7 to $31 \mathrm{mgPt} \cdot \mathrm{dm}^{-3}$, respectively. Both colour and turbidity are not linked directly to water toxicity; however, sudden changes in water turbidity and colour may imply changes in water quality resulting from organic, non-organic or biological pollutant occurrence (Witczak et al. 2013). In the analysed water samples, dry residue varied from 482 to 693 $\mathrm{mg} \cdot \mathrm{dm}^{-3}$. Determined concentrations of total iron occurred mainly within the range from 0.00 to $0.56 \mathrm{mgFe} \cdot \mathrm{dm}^{-3}$. It was only in January 1995 that the value was higher, reaching $1.13 \mathrm{mgFe} \cdot \mathrm{dm}^{-3}$ in the Różany Strumien. In the years from 1988 to 2012, manganese was found in the Różany Strumień only, and its concentration maximum limits amounted to $0.33 \mathrm{mgMn} \cdot \mathrm{dm}^{-3}$.

Table 2 compares the concentrations of heavy metals, fluorides and bromides determined at RS3 sampling point in the years 2011 and 2012. The values of parameters concentrations were insignificant. Substances particularly harmful to the aquatic environment did not exceed the limits applicable for classes I-II.

During the physical and chemical research of Lake Umultowskie, carried out in 2006, the researchers determined indicators such as transparency (Secchi depth), total phosphorus and chlorophyll $a$ (Table 3). The trophic index of lake waters, following Carlson (1977), calculated on the basis of remaining indicators, implied the a-mesotrophic state. Transparency level matched quality class II $(\geq 1.8 \mathrm{~m})$, total nitrogen class I-II with the result of $0.83 \mathrm{mgN} \cdot \mathrm{dm}^{-3}\left(\leq 1.5 \mathrm{mgN} \cdot \mathrm{dm}^{-3}\right)$ and total phosphorus class I $\left(\leq 0.045 \mathrm{mgP} \cdot \mathrm{dm}^{-3}\right)$.

\section{Discussion}

The Różany Strumień catchment is situated within the limits of the Poznan agglomeration. The anthropogenically-changed environment of the catchment is a consequence of a railway construction, agricultural activity, housing and services estates development including road infrastructure and sewerage system. Changes in land use occurred in the early 2000's, in particular: the area of farmland was reduced, and there occurred an intensive development of residential buildings and an academic campus.

In the 1990's, the Różany Srumień was acknowledged as one of the cleanest watercourses in Poznań, and Lake Umultowskie was classified as a clean water reservoir with medium eutrophia (Mickiewicz-Wichłacz 1995). In general, the surface waters of the catchment matched water quality class I, with only a few parameters matching class II (Choiński et al. 1993, 1995, Jackowiak et al. 2002). Changes in legal regulations, water quality standards and the chemical composition of the water resulted in classifying the physical and chemical parameters of the surface water in the Różany Strumień catchment as class II or lower. 
Table 4. Comparison of average chemical composition of river water in the years 1988-2012.

\begin{tabular}{|c|c|c|c|c|c|}
\hline \multirow{4}{*}{ Indicators } & \multirow{4}{*}{ Unit } & \multicolumn{2}{|c|}{ Różany Strumień } & \multicolumn{2}{|c|}{ European rivers* } \\
\hline & & \multicolumn{2}{|c|}{ Average values (No. of samples) } & \multirow{2}{*}{\multicolumn{2}{|c|}{ Average values (No. of samples) }} \\
\hline & & \multicolumn{2}{|c|}{ 1988-2012 } & & \\
\hline & & 1988-2002 & 2006-2012 & 1988-2002 & 2006-2012 \\
\hline \multicolumn{6}{|c|}{ Oxygen condition indicators } \\
\hline \multirow{2}{*}{ Dissolved oxygen } & \multirow{2}{*}{$\mathrm{mg} \cdot \mathrm{dm}^{-3}$} & \multicolumn{2}{|c|}{$9.2(26)$} & \multicolumn{2}{|c|}{$9.9(795632)$} \\
\hline & & $9.2(25)$ & $10.0(1)$ & $9.6(348049)$ & $10.3(269109)$ \\
\hline \multirow{2}{*}{$\mathrm{BOD}_{5}$} & \multirow{2}{*}{$\mathrm{mg} \cdot \mathrm{dm}^{-3}$} & \multicolumn{2}{|c|}{$3.8(25)$} & \multicolumn{2}{|c|}{$3.3(573987)$} \\
\hline & & $3.9(24)$ & $1.8(1)$ & $4(234728)$ & $2.3(237855)$ \\
\hline \multirow{2}{*}{ COD-Mn } & \multirow{2}{*}{$\mathrm{mg} \cdot \mathrm{dm}^{-3}$} & \multicolumn{2}{|c|}{$8.3(25)$} & \multicolumn{2}{|c|}{$9.0(256748)$} \\
\hline & & $7.6(22)$ & $13.0(3)$ & $9.4(147882)$ & $8.3(54485)$ \\
\hline & & Salinity indice & nd major ions & & \\
\hline Conductivity & $11 \mathrm{~S} \cdot \mathrm{cm}^{-1}$ & & & $442(1$ & 719) \\
\hline - & ности & $785(17)$ & $882(4)$ & 339 (7556) & 450 (149886) \\
\hline Hardness & $\mathrm{moCaCO} \cdot \mathrm{dm}^{-3}$ & & & & \\
\hline 1 & $\mathrm{H}=\mathrm{C}_{3}$ & $382(26)$ & $381(5)$ & - & $211(77357)$ \\
\hline Sulnhates & $m \sigma \cdot d m^{-3}$ & & & $66.2(7$ & 48) ${ }^{1)}$ \\
\hline Sumprates & & $120.7(26)$ & $97.3(5)$ & $139.6(366)^{2)}$ & $62.9(71456)$ \\
\hline Chlorides & $m a \cdot d m^{-3}$ & & & & \\
\hline Critoriates & mg.min & $44.5(26)$ & $59.4(5)$ & - & $55.1(77790)$ \\
\hline Hydrogen car- & $\mathrm{m} \sigma \cdot \mathrm{dm}^{-3}$ & & & & \\
\hline bonate & mg.am & $288.2(26)$ & $298.9(5)$ & - & $152.7(30832)$ \\
\hline Calcium & $m a d m^{-3}$ & & & & \\
\hline (1) & (118. & $128.0(26)$ & $130.9(5)$ & - & 53.7 (60789) \\
\hline & $m a \cdot d m^{-3}$ & & & & \\
\hline Magnesium & $\mathrm{mg} \cdot \mathrm{dm}^{-}$ & $14.9(26)$ & $13.0(5)$ & - & 11.8 (61015) \\
\hline Codium & $m^{d} m^{-3}+2$ & & & & \\
\hline Sodium & $\mathrm{mg} \cdot \mathrm{am}^{2}$ & $22.3(24)$ & $29.5(3)$ & - & $24.2(49855)$ \\
\hline Potassium & $m \alpha \cdot \mathrm{dm}^{-3}$ & & & & \\
\hline Potassium & & $3.6(24)$ & $4.4(3)$ & - & $3.9(46750)^{3)}$ \\
\hline & & Acidifica & dicators & & \\
\hline $\mathrm{nH}$ & 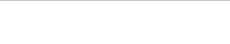 & & & $7.7(6$ & 398) \\
\hline pח & - & $7.7(25)$ & $7.6(3)$ & $7.6(247968)$ & $7.7(243385)$ \\
\hline Alkalinity & $\operatorname{moCaCO} \cdot \mathrm{dm}^{-3}$ & & & & \\
\hline НІкапाнту & 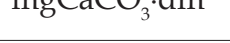 & $242.9(26)$ & $247.2(5)$ & - & $120.1(38787)^{4)}$ \\
\hline & & Biogenic co & $\mathrm{n}$ indicators & & \\
\hline Phosphates phos- & $m a d m^{-3}$ & & & 0.050 & 0522) \\
\hline phorus & mg & $0.032(26)$ & $0.015(5)$ & $0.067(350313)$ & $0.032(278608)$ \\
\hline Total phosphorus & $\mathrm{mg} \cdot \mathrm{dm}^{-3}$ & & & 0.27( & 351) \\
\hline & & $0.068(17)$ & $0.057(3)$ & $0.23(320864)$ & $0.10(230109)$ \\
\hline Ammonia nitro- & $m \sigma \cdot d m^{-3}$ & & & 0.14 & 171) \\
\hline gen & & $0.21(26)$ & $0.48(5)$ & $0.12(805)^{5)}$ & $0.14(40163)$ \\
\hline Nitrite nitrogen & $\mathrm{mg} \cdot \mathrm{dm}^{-3}$ & & & 0.018 & 6949) \\
\hline Nitrite nitrogen & mg:am & $0.018(26)$ & $0.061(5)$ & 0.019 (239138) & $0.016(216854)$ \\
\hline Nitrate nitrogen & $\mathrm{mo} \cdot \mathrm{dm}^{-3}$ & & & 0.57( & 702) \\
\hline & & $1.55(26)$ & $1.38(5)$ & $0.55(324487)$ & $0.60(271031)$ \\
\hline
\end{tabular}

Explanation: *acc. EEA (2016); ${ }^{12000-2012 ; ~}{ }^{2)} 2000-2002$ Italy; ${ }^{3)} 2009-2012 ;{ }^{4} 2008-2012 ;{ }^{5}$ Lichtenstein.

The average values of indicators of the river water in the years 1988-2012 are shown in Table 4. The concentrations recorded in the analyzed water samples are more similar to the parameter values of rivers in urban areas (see Dąbkowski,
Pawłat-Zawrzykraj 2003, Ciupa 2009, WysockaCzubaszek, Wojno 2014) than to the chemical composition of natural European river waters (see Berner, Berner 1987). The colour of natural, not contaminated water, is usually $5-20 \mathrm{mgPt} \cdot \mathrm{dm}^{-3}$ 
(Dojlido 1995). The colour of the analyzed water is periodically $>20 \mathrm{mgPt} \cdot \mathrm{dm}^{-3}$. A comparison of the average chemical composition of river water in the Różany Strumień catchment to the average chemical composition of European river water observed during the last years is presented in Table 4 (EEA 2016). The researchers noticed higher concentrations of nitrate nitrogen, conductivity, alkalinity and hardness (as well $\mathrm{HCO}_{3}$ and Ca) in the Różany Strumień.

A variability analysis of physical and chemical parameters in the catchment surface waters, conducted between 1988 and 2012, reveals that the waters may be described as hard (200-300 $\left.\mathrm{mgCaCO}_{3} \cdot \mathrm{dm}^{-3}\right)$ and very hard $(>300$ $\left.\mathrm{mgCaCO} \cdot \mathrm{dm}^{-3}\right)$, mostly having slightly base reaction (Dojlido 1995). The researchers observed the following changes in the major ions concentrations in the waters of the analyzed catchment: a hydrogeochemical water type changed from calcium, hydrogen carbonate and sulphates to calcium, hydrogen carbonate sulphates and chloride and calcium, sodium, hydrogen carbonate, sulphates and chloride.

In order to establish trends in chemistry changes in the surface waters of the Różany Strumien catchment resulting from the transformations in land use, the researchers compared average values of particular physical and chemical parameters determined in the years 1988-2002 and 2006-2012 (Table 4). In that respect, one can recognise an unfavorable change in water quality of the Różany Strumień in terms of COD-Mn, conductivity, chlorides, sodium, ammonia nitrogen or nitrite nitrogen. At the same time, decreased values of indicators such as phosphates and sulphates can be observed.

The correlation of high concentrations of phosphates, turbidity and manganese in the first observation period, attributable to winter time, indicates an increased transport of these substances from the catchment area to its surface waters. Lower phosphate concentrations in Różany Stumień water in recent years may result from: 1 ) the binding of phosphorus by plants during spring months, 2) less erosion of phosphorus-absorbed soil, 3) the decreasing area of agricultural land.

The migration of nitrate in the environment, from the source of contamination to the receiver, occurs in a different manner than in the case of phosphates. For example, transport is not slowed down by adsorption processes. In the years 1988-2012, there occurred periods of high concentrations of nitrates. It could be attributed to the inflow of pollutants from several potential pollution sources in the catchment: agricultural land, gardens or built-up areas.

The higher concentrations of nitrogen compounds in the form of ammonia nitrogen and nitrite nitrogen have been observed in recent years in the spring, summer and autumn months. The form of nitrogen compound occurrence may imply the existence of a source of pollution located relatively close to the measuring point (Dojlido 1995). This would indicate a connection with the recent intensive development of, among other things, housing estates and public buildings, in the central part of the catchment. Pollution with nitrogen compounds could possibly result from anthropogenic activities within the catchment, such as domestic sewage or applying fertilizers in home gardens or green areas.

Lower concentrations of sulphates, observed, for instance, at base stations of the Integrated Environmental Monitoring, are a result of a lower sulphur dioxide content in the air as well as a lower content of sulphates in precipitation (Kostrzewski et al. 2011).

An increase in chloride and sodium concentrations in urban areas is usually a result of the impacts of the transport infrastructure and domestic pollution (Dojlido 1995).

Urbanization causes changes in the hydrological conditions in the catchment. The sealing surface, associated with the development of buildings, reduces the circulation time of water and can lead to a faster flow of pollutants from the source to the receiver - river or lake.

\section{Conclusions}

The conducted variability analysis of selected physical and chemical properties of surface waters in the Różany Strumień catchment area in the years 1988-2012 found that the surface waters in the catchment belong to hard and very hard, slightly basic type of waters. As observed, hydrogeochemical type of water transformed from calcium-hydrogen carbonate-sulphate to calcium-sodium-hydrogen carbonate-sulphate-chloride. 
The catchment waters, in terms of their physical and chemical parameters, are often classified as class II or lower (concentrations of indicators exceed the limit values of quality class II). In recent years the deterioration of Różany Strumień water quality was observed in terms of the chemical oxygen demand, conductivity, chlorides, sodium, ammonia nitrogen and nitrite nitrogen concentrations. A decrease of phosphates and sulphates in the water was also noticed.

Changes in water chemistry are most likely a result of anthropogenic impacts and are associated with transformations in land use in the catchment area - the ongoing urbanization process of the area.

Transferring the research results of surface water chemistry onto other catchments is difficult for the chemical composition of surface waters is influenced by factors such as geological structure, climate, intensity of flow, vegetation, land use and other. The chemical composition of water indicates that the surface water of the Różany Strumień catchment deviates from the chemical composition of natural river waters. The researchers observed higher values of conductivity, alkalinity, hardness and nitrogen compounds in the Różany Strumień water, compared to average values of European rivers water indicators.

Physical and chemical water analyses conducted irregularly or, from 2008 onwards, at only one sampling point, do not show the whole picture of surface water quality within the catchment. As a result of the ongoing urban development within the area of research, the significance of organized physical and chemical parameter analyses of surface waters in the Różany Strumień catchment is still growing.

\section{Acknowledgments}

Physical and chemical analyses of 2006 to 2012 presented in this study were obtained as part of a research project of the Ministry of Science and Higher Education N525 018 32/2038 and of a research project of the National Science Center DEC-2011/01/B/ST10/02063.

We would like to thank Professor M. Marciniak for providing access to a master's dissertation written under his guidance, and Doctors $\mathrm{Z}$. Ziętkowiak and P. Klimaszyk for providing access to the source data.
We would also like to thank the Reviewers for their insightful and helpful comments on the article.

\section{References}

Andrzejak A., Marchwińska A., Nochowicz B., Ogór T., Peis M., Staśkiewicz Z., Sypniewski J., Wrzesiński W., 2013. Warunki odpływu w zlewni Różanego Potoku w okresie zimowym (Runoff conditions within the Różany Strumień catchment in winter season). In: A. Kostrzewski (ed.), Geoforum. T. 1, 90 lat Studenckiego Koła Naukowego Geografów w Poznaniu (1923-2013). Bogucki Wydawnictwo Naukowe, Poznań: 59-63.

Atlas podziatu hydrograficznego Polski (Atlas of Poland's drainage system). H. Czarnecka (ed.), IMGW, Warszawa, 2005.

Bazyly J., 2003. Monitoring obiegu wody w zlewni Strumienia Różanego w Poznaniu (Monitoring of water cycling in the catchment of the Różany Strumień in Poznań). Master's dissertation, archive of Zakład Hydrometrii WNGiG UAM, Poznań.

Berner E.K., Berner R.A., 1987. The global water cycle. Geochemistry and environment. Prentice Hall, Englewood Cliffs, New Jersey.

Carlson R.E., 1977. A tropic state index for lakes. Limnol. Oceanogr. 22(2): 361-369.

Choiński A., 2006. Katalog jezior Polski (Directory of Poland's Lakes). Wyd. Nauk. UAM, Poznań.

Choiński A., Gogołek A., Kaniecki A., Marciniak M., Ziętkowiak Z., 1995. Charakterystyka zlewni Różanego Potoku (The characteristic of the Różany Strumień catchment). In: A. Kaniecki, J. Rotnicka (eds), Wody powierzchniowe Poznania. Problemy wodne obszarów miejskich. Wyd. Sorus, Poznań: 304-313.

Choiński A., Kaniecki A., Marciniak M., Ziętkowiak Z., 1993. Warunki ochrony i zachowania Różanego Potoku (Terms on protection and preservation stipulated for the Różany Potok). Typescript, archive of Zakład Hydrologii i Gospodarki Wodnej WNGiG UAM, Poznań.

Ciupa T., 2009. Wpływ zagospodarowania terenu, w tym urbanizacji, na stężenie głównych jonów w wodach rzeki Silnicy i Sufragańca (Kielce) (The influence of land use, including urbanization, on major ion concentration, in the waters of the Silnica and Sufraganiec rivers (Kielce)). Ochrona Środowiska i Zasobów Naturalnych 38: 44-53.

Dąbkowski S.L., Pawłat-Zawrzykraj A., 2003. Jakość wód Raszynki i jej dopływów (Water quality of the Raszynka river and its tributaries). Woda-Środowisko-Obszary Wiejskie 3 (6): 111-123.

Dojlido J.R., 1995. Chemia wód powierzchniowych (Chemistry of surface waters). Wyd. Ekonomia i Środowisko, Białystok.

Dzwoniarski J., 1988. Zdjęcie hydrograficzne pótnocnego pasma obszaru miasta Poznania (Hydrographic mapping of the City of Poznań northern part). Typescript, archive of Zakład Hydrologii i Gospodarki Wodnej WNGiG UAM, Poznań

EEA [The European Environment Agency], 2016. Waterbase - Rivers. Online: http://www.eea.europa.eu/data-andmaps/data/waterbase-rivers-10 (accessed December 31, 2016). 
GUGiK [Główny Urząd Geodezji i Kartografii], 2016. Geoportal 2. Online: www.geoportal.gov.pl (accessed December 31, 2016).

Jackowiak B., Przybyłek J., Ziętkowiak Z., 2002. Opracowanie ekofizjograficzne dot. miejscowego planu zagospodarowania przestrzennego "terenów rozwojowych UAM na Morasku w Poznaniu" (Environmental and physiographical study on the zoning plan of the Adam Mickiewicz University developmental area in Morasko in Poznań). Typescript, archive of Zakład Hydrogeologii i Ochrony Wód WNGiG UAM, Poznań.

Jańczak J., Sziwa R., 1995. Charakterystyka morfometryczno-hydrologiczna jezior i zbiorników wodnych Poznania (Morphometric and hydrological characteristics of lakes and water reservoirs in Poznań). In: A. Kaniecki, J. Rotnicka (eds), Wody powierzchniowe Poznania. Problemy wodne obszarów miejskich. Wyd. Sorus, Poznań: 344-355.

Klimaszyk P., 2006. Fizyczno-chemiczne i biologiczne właściwości wód użytku ekologicznego "Jezioro Umultowskie" (Physical and chemical water properties of the Lake Umultowskie ecological site). Typescript, archive of Zakład Ochrony Wód WB UAM, Poznań.

Kolada A., Soszka H., Cydzik D., Gołub M., 2005. Abiotic typology of Polish lakes. Limnologica 35: 145-150.

Kostrzewski A., Szpikowski J, Szpikowska G., 2011. Stan geoekosystemów Polski - ocena na podstawie wybranych geowskaźników w programie Zintegrowanego Monitoringu Środowiska Przyrodniczego (The condition of Poland's geoecosystems - evaluation on the basis of selected geoindicators as part of Integrated Environmental Monitoring Program). Monitoring Środowiska Przyrodniczego 12: 69-83.

Kowalczak P. i in., 1989. Ocena natężenia przeptywów w ciekach oraz rejestracja stanów wody w zbiornikach osiedla "Morasko" w okresie wystapienia suszy hydrologicznej we wrześniu 1989 (Flow evaluation in the watercourses and water state records in the reservoirs of Morasko district, when hydrological drought occurred in September of 1989). Przed. Projekt. Wyk. HYDROPOL, Poznań.

Kowalik A., 2005. Zmiany sieci hydrograficznej na obszarze Poznania w latach 1945-2000 (Changes in a hydrographic network within the territory of Poland in the years from 1945 to 2000). Materiaty Badawcze IMGW, series: Hydrologia i oceanologia 31.

Mapa Sozologiczna Polski w skali 1:50 000 (Sozological Map of Poland on a scale of 1:50 000), Poznań (N-33-130-D). GUGiK, Warszawa, 2004.

Mickiewicz-Wichłacz D., 1995. Stan czystości wód powierzchniowych Poznania (Purity state of surface waters in Poznań). Gazeta Obserwatora IMGW 44(1): 12-14.

Molenda T., 2010. Krótkookresowe zmiany fizyczno-chemicznych właściwości wód rzecznych w zlewni zurbanizowanej (Short-term changes in physical-chemical properties of river waters in urbanized catchment). Studia i Prace z Geografii i Geologii 13: 85-91.
Okońska M., Marciniak M., 2009. Identyfikacja parametrów migracji wybranych znaczników w warstwie wodonośnej metoda modelowania numerycznego (Identification of migration parameters of selected tracers in aquifer by means of numerical modeling method). Factual report of research project N525 018 32/2038, archive of Zakład Hydrometrii WNGiG UAM, Poznań.

Pazdro Z., Kozerski B., 1990. Hydrogeologia ogólna (General hydrogeology). Wyd. Geol., Warszawa.

Rocznik statystyczny Poznania 2003 (Statistical yearbook of Poznań 2003). Urząd Statystyczny w Poznaniu, Poznań, 2003.

Rocznik statystyczny Poznania 2009 (Statistical yearbook of Poznań 2009). Urząd Statystyczny w Poznaniu, Poznań, 2009.

Rocznik statystyczny Poznania 2011 (Statistical yearbook of Poznań 2011). Urząd Statystyczny w Poznaniu, Poznań, 2011.

Rocznik statystyczny Poznania 2013 (Statistical yearbook of Poznań 2013). Urząd Statystyczny w Poznaniu, Poznań, 2013.

Rozporządzenie Ministra Środowiska z dn. 21.07.2016 r. w sprawie sposobu klasyfikacji stanu jednolitych części wód powierzchniowych oraz środowiskowych norm jakości dla substancji priorytetowych (Regulation of the Minister of Environmental as of 21st July 2016 on the classification method of the surface water uniform parts' condition and on the environmental quality standards of preferential substances). Dz.U. poz. 1187.

Sojka M., Murat-Błażejewska S., Wróżyński R., 2014. Analiza możliwości wykorzystania modeli hydrologicznych $\mathrm{w}$ strategicznej ocenie oddziaływania na środowisko miejscowych planów zagospodarowania przestrzennego (Analysis of potential adoption of hydrological models to strategic assessment of zoning plans' environmental impact). Inżynieria Ekologiczna 39: 176-186.

Szczegótowa Mapa Geologiczna Polski w skali 1:50 000 (Detailed Geological Map of Poland on a scale of 1:50 000), Poznań (471). PIG Warszawa, 1996.

Witczak S., Kania J., Kmiecik E., 2013. Katalog wybranych fizycznych i chemicznych wskaźników zanieczyszczeń wód podziemnych i metod ich oznaczania (Catalogue of selected physical and chemical pollution indicators of ground waters and of their identification methods). Bibl. Monit. Środ., Warszawa.

Wysocka-Czubaszek A., Wojno W., 2014. Sezonowa zmienność chemizmu wody w małej rzece w zlewni zurbanizowanej (Seasonal changes of water chemistry in a small river in an urban catchment). Prz. Nauk. Inż. Kszt. Środ. 63: 64-76.

Ziętkowiak Z., 2003. Ocena zmian jakości wody w Strumieniu Różanym (The assessment of water quality changes in the Różany Strumień). Przegląd Geol. 51(11): 955-956. 